\title{
塩酸グアニジンの吸湿特性に及ぼす添加剤と包装材料の影響
}

\author{
寺岡麗子 $*^{*} \dagger^{1}$, 松田芳久 $\dagger^{1}$, 杉本 功 $\dagger^{2}$ \\ 神戸薬科大学製剂学研究室 $\dagger^{1}$ \\ (財)田附興風会 北野病院薬剂部 $\dagger^{2}$
}

\section{Effects of Diluents and Packing Materials on the Hygroscopic Properties of Guanidine Hydrochloride}

\author{
Reiko Teraoka ${ }^{*} \dagger^{1}$, Yoshihisa Matsuda $\uparrow^{1}$ and Isao Sugimoto $\dagger^{2}$ \\ Department of Pharmaceutical Technology, Kobe Pharmaceutical University $\dagger^{1}$ \\ Department of Pharmacy, Kitano Hospital, the Tazuke Kofukai Medical Research Institute $\dagger^{2}$
}

$\left[\begin{array}{l}\text { Received April 13, } 2002 \\ \text { Accepted August 3, } 2002\end{array}\right]$

\begin{abstract}
Guanidine hydrochloride, which is known to be effective in the treatment of Lambert-Eaton myasthenic syndrome, is very hygroscopic. Therefore, the mixture of the drug and lactose dispensed at hospital pharmacies tends to easily liquefy even under ordinary storage conditions because of poor compatibility. In this study the physicochemical and chemical stabilities of commercially available guanidine salts, namely hydrochloride, nitrate, carbonate, and sulfate, were investigated at various relative humidity levels. The critical relative humidity of the hydrochloride salt was significantly lower than the others and it was also more hygroscopic than the other three salts, however, nitrate was found to be sufficiently stable regarding humidity. The powder maintained a good flowability after long storage periods. The optimal diluent was selected to use in powders consisting of guanidine hydrochloride in order to stabilize the physicochemical and chemical properties. No solidification or change in appearance were observed in the mixture of the drug and magnesium aluminometasilicate (Neusilin ${ }^{\circledR} \mathrm{US}_{2}$ ) as diluent and moisture adsorbent. The flow property (angle of repose) of this mixture was also investigated.
\end{abstract}

Keywords - guanidine hydrochloride, hygroscopic properties, angle of repose, magnesium aluminometasilicate, diluent, packing material

\section{緒言}

Lambert-Eaton 症候群は筋無力症状を主徴とする慢性 疾患で，小細胞肺癌などの悪性腫瘍も合併することがあ る。治療薬として, 塩酸グアニジンの有効性が報告され ている ${ }^{1-4)}$ が, 日本では治療薬として許可されていない. このように，既存の医薬品では対処できない疾患に対し て薬効を示す化合物類を，患者に適用しやすい投与形態
に調製する必要があるが, この際に有効性, 安全性, 安 定性等に十分に留意して調製しなければならない.山下 ら ${ }^{4)}$ は，投与剤形として内用水剤を選択し，この水剂が 室温, 冷所保存下で 3 週間安定であったことを報告して いる. しかし, 内用液剤は細菌污染の観点から長期保存 は避けるべきであり，特に水剂の保存は 1 週間を限度と すべきである5).

ところで，薬効を示す新規化合物の溶解性を改善する

$\dagger^{1}$ 兵庫県神戸市東灘区本山北町 4-19- 1 ； 4-19- 1, Motoyama-Kitamachi, Higashi-Nada-ku, Kobe-shi, Hyogo, 658-8558 Japan

$\dagger^{2}$ 大阪市北区扇町 2-4-20；2-4-20, Ohgimachi, Kita-ku, Osaka-shi, 530-8480 Japan 
ために，その塩が用いられているが，選択された塩は融 点, 吸湿性, 化学的安定性, 溶出速度, 溶解度, 結晶形 等の特性に広く影響を及ぼすことが知られている。一般 に，塩基性の難水溶性医薬品を易溶性とするために鉱酸 類（塩酸, 硫酸, 硝酸など）の塩または有機酸の塩が選 択されている。しかし, 塩酸塩とした場合, 遊離した塩 酸が打錠機の杵の腐食や, 薬物の安定性の低下をもたら すことや吸湿性が高くなることが知られている，塩酸グ アニジンは一般的な塩酸塩と同様に強い吸湿性を有する が, このような吸湿性が著しい特殊薬剂を散剤として調 製する場合には湿度に対する保存安定性が問題となる。 そこで本報ではまず，4種類のグアニジン鉱酸塩の吸湿 性に関する基礎的なデー夕を得るために，これらを種々 の相対湿度下で保存し, 吸湿特性を比較検討した.さら に調製する散凨の吸湿安定性を改善するために, 種々の 添加剤を配合し, これらの混合粉体の吸湿特性と外観変 化についても検討した.

また，混合散剤の自動分包機による包装中での吸湿变 化についても検討した.

\section{実験 の 部}

\section{1. 試薬}

グアニジン塩酸塩，グアニジン硝酸塩，グアニジン炭 酸塩，グアニジン硫酸塩は和光純薬工業株式会社から購 入した。粉末乳糖（Pharmatose ${ }^{\circledR} 200 \mathrm{M}$ ）は DMV International, 結晶セルロース ( $\mathrm{PH}-101)$ は旭化成株式会社, メタケイ酸アルミン酸マグネシウム(ノイシリン $\mathrm{NFL}_{2} \mathrm{~N}$, $\left.\mathrm{US}_{2}, \mathrm{UFL}_{2}\right)$ は富士化学工業株式会社から提供を受けた。 これらの試料粉末はノイシリン US 2 以外はすべて篩過 し，125 250 $\mu \mathrm{m}$ の粒度範囲のものを使用した。 ノイシ リン $\mathrm{US}_{2}$ はこの粒度範囲以下の微粒子であったので，そ のまま使用した．添加剤と薬物は $1 ： 1$ の重量比で V 型混合機を用いて混合し，いずれの試料も実験前に室温 で一夜減圧乾燥して使用した。その他の試薬は特級市販 品を使用した。

\section{2. 分包}

グラシン紙（パルプにポリエチレン加工を施した紙） による包装は試料 $150 \mathrm{mg}$ を全自動散薬分包機 DOUBLE SAUCER REVERSE CONSTRUCTION yuyama YS-48 WR-SV（株式会社湯山製作所）を用いて行った。セロ ポリ（中圧法ポリエチレン樹脂）による包装は，試料150 $\mathrm{mg}$ を卓上型分包機スミレ・パイルパッカー707型（す みれ分包機株式会社）を用いて行った。

\section{3. 吸湿試験}

いずれの試料も約 $200 \mathrm{mg}$ を秤量ビンに入れ，種々の
塩類飽和溶液により $25^{\circ} \mathrm{C}$ で $51 \%$ 相対湿度 $(\mathrm{RH})($ 硝酸力 ルシウム 4 水和物), $62 \% \mathrm{RH}$ (硝酸アンモニウム), $75 \%$ $\mathrm{RH}$ (塩化ナトリウム), $84 \% \mathrm{RH}$ (塩化カリウム), $90 \%$ $\mathrm{RH}$ (塩化バリウム 2 水和物)，97\%RH（硫酸カリウム) に保ったスチロール容器中に保存した。各試料の重量増 加を経時的に測定して吸湿等温線を作成し, 臨界相対湿 度 $(\mathrm{CRH})$ を求めた。

\section{4. 安息角の測定}

吸湿前の試料と $25^{\circ} \mathrm{C}, 75 \% \mathrm{RH}$ で 5 時間保存した試料 を，スパチュラを用いて漏斗から円錐上の堆積体の高さ が一定になるまで，テーブル（直径 $6 \mathrm{~cm}$ ）の上に静か に供給した。その円錐上の堆積体の高さ $(\mathrm{h})$ とテーブル の半径 $(\mathrm{r})$ から安息角 $(\Phi)$ を(1) 式によって求めた. 各試料とも 5 回ずつ測定し, その平均值を求めた.

$$
\Phi=\tan ^{-1}\left(\frac{h}{r}\right)
$$

\section{5. 外観変化}

吸湿試験開始64時間後の試料の外観変化について肉眼 的に観察した。 その場合の判定基準は次に示すものに 従った。

外観変化の判定

$$
\begin{aligned}
& - \text { : 変化がほとんど認められなかった } \\
& \quad \pm: \text { 少し固化した } \\
& + \text { : :固化または少し湿潤した } \\
& ++ \text { : 湿潤した } \\
& +++ \text { : 液化した } \\
& \text { また, これらの変化をデジタルカメラで撮影した. }
\end{aligned}
$$

\section{6. 塩酸グアニジンの定量}

既報6)に従い，塩酸グアニジンとノイシリン $\mathrm{US}_{2}$ 等量 混合物 $10 \mathrm{mg}$ を精秤し, 精製水 $2 \mathrm{~mL}$ を加えて塩酸グア ニジンを溶解後， $2 \mathrm{~N}$ 水酸化ナトリウム試液 $1 \mathrm{~mL}, \mathrm{VP}$ 試薬（ $5 \mathrm{w} / \mathrm{v} \% \alpha$-ナフトール，0.025v/v\%ジアセチル

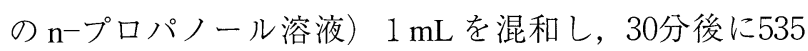
$\mathrm{nm}$ における吸光度を測定した。別に混合散剤を加えな いブランク溶液についても同様に吸光度を測定した。

\section{結果および考察}

\section{1. 種々のグアニジン塩の吸湿性}

実際に患者に投与されている塩酸グアニジンとその他

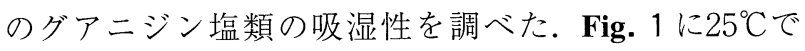
種々の相対湿度下に保存したグアニジン塩の経時的な重 量増加率を示す. Fig. 1 に示すように塩の種類によって 増加率には著しい相違が認められた。すなわち, 塩酸塩 

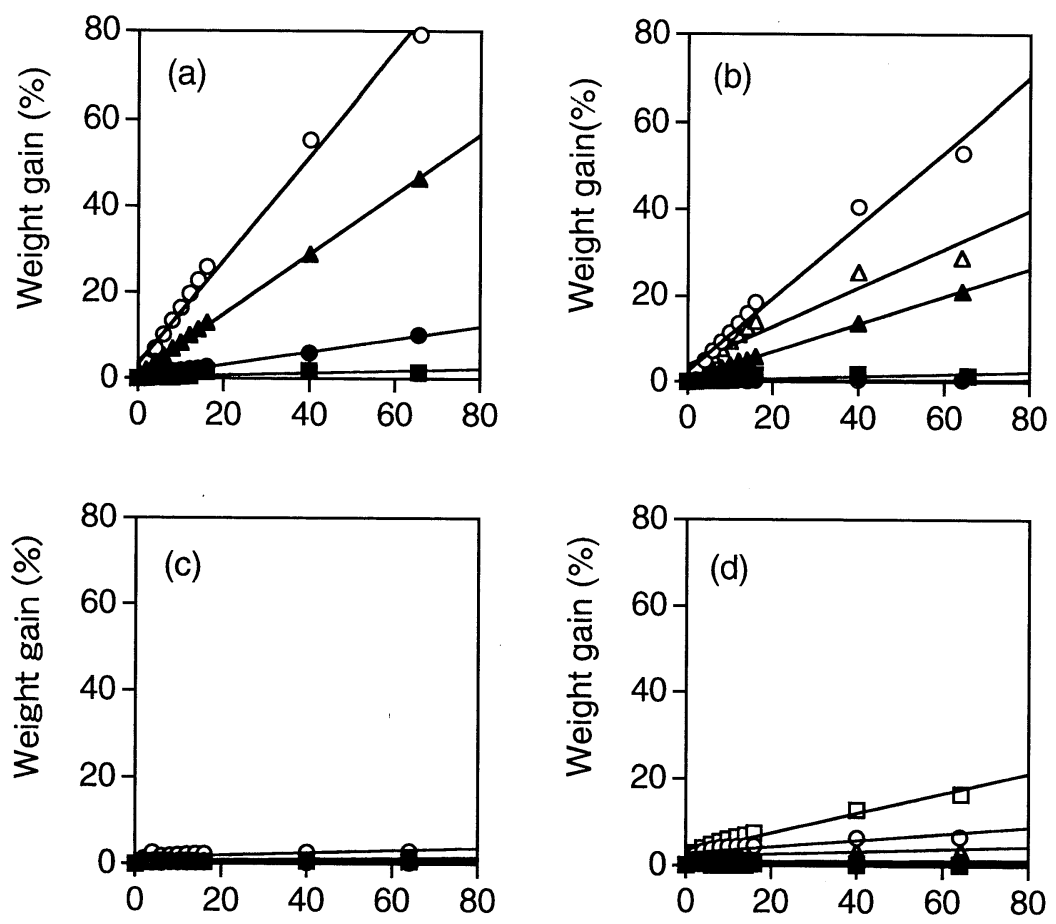

Time (h)

Time (h)

Fig. 1. Changes of Weight Gain of Guanidine Salt Powders under Various Humidity Conditions at $25^{\circ} \mathrm{C}$.

(a) Hydrochloride; (b) Sulfate ; (c) Carbonate ; (d) Nitrate

, $51 \% \mathrm{RH} ; \boldsymbol{O}, 62 \% \mathrm{RH} ; \boldsymbol{\Delta}, 75 \% \mathrm{RH}$;

$\triangle, 84 \% \mathrm{RH} ; \bigcirc, 90 \% \mathrm{RH} ; \square, 97 \% \mathrm{RH}$

と硫酸塩は強い吸湿性を示し， $25^{\circ} \mathrm{C} ， 75 \% \mathrm{RH}$ での64時 間後の重量増加率は，それぞれ $46 \%$ と $21 \%$ に達したが, 逆に炭酸塩と硝酸塩ではほとんど重量増加を示さなかっ た。また，いずれのグアニジン塩においても各相対湿度 下で時間と重量増加率の間に良好な直線性が得られたの で，これらの回帰直線の傾きから吸湿速度定数を求め た.そして，これらの吸湿速度定数の值を各相対湿度に 対してプロットした（Fig. 2).いずれのグアニジン塩 においても両者の間には良好な直線関係が得られたの で,これらの直線の回帰式から, 直線を吸湿速度 $=0$ (す なわち $\mathrm{x}$ 軸）に外挿して臨界相対湿度 ( $\mathrm{CRH}$ )を計算 した（Table 1).グアニジン塩の CRH は硝酸塩＞炭酸 塩>硫酸塩>塩酸塩の順に小さくなり, 塩酸塩がもっと も吸湿性が強いことが確認された。一般に $25^{\circ} \mathrm{C}$ で $\mathrm{CRH}$ が50\%RH 以下の物質が吸湿性物質とみなされている が，塩酸塩の CRH は57.3\%RH であったことから，塩 酸塩はかなり吸湿性が高いことがわかった。 Table 1 お よびFig. 3 にグアニジン塩を種々の相対湿度下で64時 間保存した後の外観変化を示した。硝酸塩は75\%RHよ り低い保存湿度下で変化が認められず，極めて安定であ

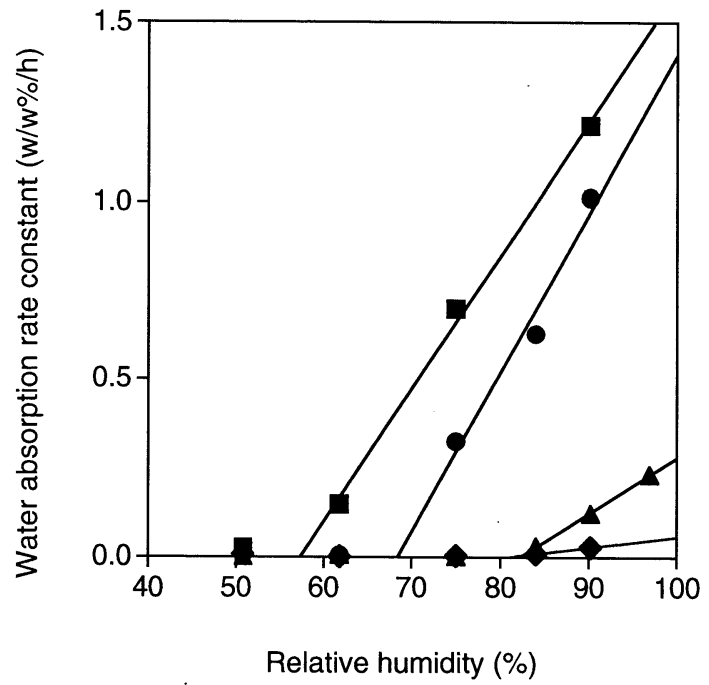

Fig. 2. Effect of Relative Humidity on the Water Absorption Rate Constant of Various Guanidine Salts.

$\boldsymbol{\square}$, Hydrochloride ; $\boldsymbol{O}$, Sulfate ; $\boldsymbol{\Delta}$, Nitrate ;

$\diamond$, Carbonate 
Table 1. Changes in Liquidity and Critical Relative Humidity of Four Guanidine Salts Stored at $25^{\circ} \mathrm{C}$ and Various Relative Humidities.

\begin{tabular}{lccccc}
\hline \multirow{2}{*}{ Guanidine salt } & \multicolumn{3}{c}{ Relative humidity(\%) } & \multirow{2}{*}{ Critical relative humidity $(\%)$} \\
\cline { 2 - 5 } & 51 & 62 & 75 & 90 & \\
\hline Hydrochloride & + & ++ & +++ & +++ & 57.3 \\
Sulfate & - & + & +++ & +++ & 68.5 \\
Nitrate & - & - & - & + & 82.2 \\
Carbonate & + & + & + & + & 81.1 \\
\hline
\end{tabular}

Symbols used are as follows:

-: no appearance change was observed; +: solidification or a slight wetting were observed; ++: appreciable wetting was observed; +++: liquefaction was observed and the sample lost characteristics of powder
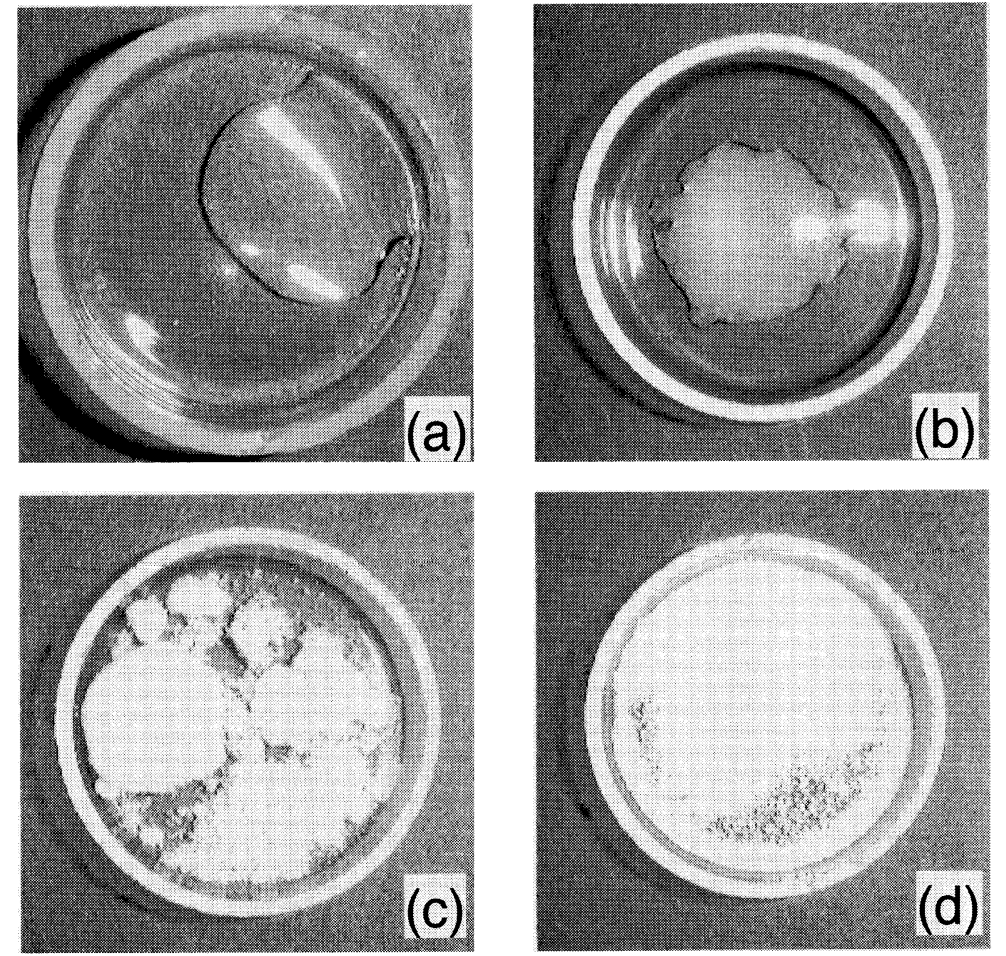

Fig. 3. Appearance Changes of Four Guanidine Salts after Storage at $75 \%$ RH for $64 \mathrm{~h}$.

(a) Hydrochloride; (b) Sulfate; (c) Carbonate ; (d) Nitrate

ることが明らかとなった。また，Fig. 3 からも75\%RH 下でも湿潤や固化は起こっていないことを確認した。一 方, その他の塩ではほとんどの湿度条件下で湿潤, 固 化, 液化現象が認められた. 特に塩酸塩では $51 \%$ RH の 低い湿度条件から湿潤がみられ，75\%RH 以上では完全 に液化した。これはFig. 3 からも明らかで, 他に硫酸 塩においてもかなりの潮解現象が観察されたが, 炭酸塩
において潮解ではなく，一部湿潤固化する現象が認めら れ，塩の種類によって吸湿による外観変化が異なること が明らかとなった。

ところで，粉体の流動性は一般的には休止角（安息 角）で評価され，測定条件を一定にすれば再現性のある 数值が得られる. そこで, 保存前後の試料の安息角を残 留円錐法によって測定し Table 2 に示した. 保存前のグ 
アニジン塩類の安息角はいずれの試料も $45^{\circ}$ 前後でほほ 同じ值を示し，流動性の良い粉体であったが，75\%RH 下で 5 時間保存すると，いずれの塩においても安息角が 増加した。保存による変化の度合いを比較するために保 存前後の安息角比を求めたところ, 硫酸塩はほほ1.1と なり, 保存後も流動性は変化しなかったが, 塩酸塩では 1.3 と 4 種類の塩の中ではもっとも大きな值を示し, 保 存によって流動性が最も低下することが明らかとなっ た．難溶性の塩基性薬物の溶解度を改善するためには塩 酸塩とされる場合が多いが7, 塩によって物理化学的特 性が異なるので, 塩の選択の際には多方面から十分に検 討する必要があると考えられる.

\section{2. 塩酸グアニジンと添加剤の等量混合物の吸湿特性}

現在, Lambert-Eaton 症候群に用いられている塩酸グ アニジンは, 容易に吸湿し, 潮解するので, 分包散郕と して交付することができない.そこで, 保存後も散剤と しての性質を維持することを目的として, 吸水能が高い 賦形剂と混合した。メタケイ酸アルミン酸マグネシウム （ノイシリン）は優れた制酸剤として胃腸薬製郕原料と してよく使用されており，また，比表面積が非常に大き く, 高い吸油, 吸着能を有し, 分散性にも優れているの で, 賦形剤, 結合剤, 崩壊剤や吸着粉末化剂として錠 剤, 散剂, 顆粒剂などの品質を改善する目的で用いられ ている.ノイシリンは，用途に合わせて種々のタイプの 製品が市販されているが，吸水量ができるだけ大きい中 性の 3 種類のタイプを選択した。これらの中で, $\mathrm{NFL}_{2}$ は軽質低水分粉末, UFL 2 は特軽質低水分粉末, US 2 は大 プレードライ品で, 微粒の低水分粉末である. Fig. 4 は これら 3 種類のノイシリンと, 賦形剤として沉用されて いる乳糖㧍よび結晶セルロースの種々の相対湿度下での 吸湿による重量増加の経時変化を示している。乳糖およ び結晶セルロースはいずれも $75 \%$ RH 以下では重量増加 がほとんど認められなかったが, 最も高湿度の $90 \% \mathrm{RH}$ では結晶セルロースでわずかな重量増加が認められた。
一方，ノイシリンはいずれのタイプに打いても低湿度条 件下でも重量が増加し，90\%RH で62時間保存した場 合, ノイシリン重量の $30 \%$ 程度の水分を吸着した。

Fig. 5 は種々の相対湿度下での塩酸グアニジンと添加剤 の等量混合物の重量増加の経時変化を示している。いず れの添加剤との混合物でも保存時間が長くなるに従って 吸湿量の増加が認められ，90\%RH で62時間保存すると 試料重量は約 $60 \%$ 増加したが, 吸湿後の試料の性状変化 は添加剤によって相違が認められた。 $75 \%$ RH で 5 時間 保存した塩酸グアニジンと添加剤の等量混合物の安息角 の変化を Table 3 に，また同じ湿度で64時間保存した試 料の外観変化を Fig. 6 㧍よび Table 4 に示した. Fig. 6 およびTable 4 より吸湿性をほとんど示さなかった乳糖 や結晶セルロースでは外観が大きく変化し, 乳糖では液 化し, 結晶セルロースでは吸湿による固化現象がみら れ，散剂としての形態が認められなくなった。しかし， ノイシリンを混合した試料では, 重量が増加し吸湿して いるにもかかわらず，外観がほとんど変化せず，保存前 の散剤の状態を維持していた，原体の保存前後の安息角 比は1.3と大きかったが， 3 種類のノイシリンの等量混 合物はいずれもほぼ1であった。これらのことから，原 体は吸湿によって流動性が低下するが，ノイシリンとの 等量混合物では吸湿しても流動性がまったく変化せず, 散剂としての機能を失わないことが明らかとなった。特 にノイシリン $\mathrm{US}_{2}$ 等量混合物は逆に原体の安息角よりも 小さくなり, 原薬の流動性も改善できた。そこで, 主薬 の均一性を確認するために, ノイシリン $\mathrm{US}_{2}$ の混合粉体 層の10カ所からランダムに一定量の試料を採取し，含有 する塩酸グアニジン量を測定し，その変動係数を求め た。混合性の評価として求めた変動係数は $6.12 \%$ あっっ たが，混合良好と判定される ${ }^{8} 6.08 \%$ に近似した值で あったことから，この散剂中で主薬の均一性がほほ確保 されていることが明らかとなった。

以上の結果から，吸湿しやすい散剂の調剤をノイシリ ンの添加によって容易にすることができ，また流動性も

Table 2. Changes in Angle of Repose of Various Guanidine Salts Stored at $25^{\circ} \mathrm{C}$ and $75 \%$ RH for $5 \mathrm{~h}$.

\begin{tabular}{lccc}
\hline \multirow{2}{*}{ Guanidine salt } & \multicolumn{2}{c}{ Angle of repose*1 ${ }^{\circ}$ ) } & Ratio (B/A) \\
\cline { 2 - 4 } & Before storage (A) & After storage (B) & \\
\hline Hydrochloride & 43.5 & 56.6 & 1.30 \\
Sulfate & 44.5 & 47.6 & 1.07 \\
Nitrate & 45.1 & 50.9 & 1.13 \\
Carbonate & 49.8 & 56.7 & 1.14 \\
\hline
\end{tabular}

*1 Samples were stored at $25^{\circ} \mathrm{C}$ and $75 \% \mathrm{RH}$ for $5 \mathrm{~h}$. 

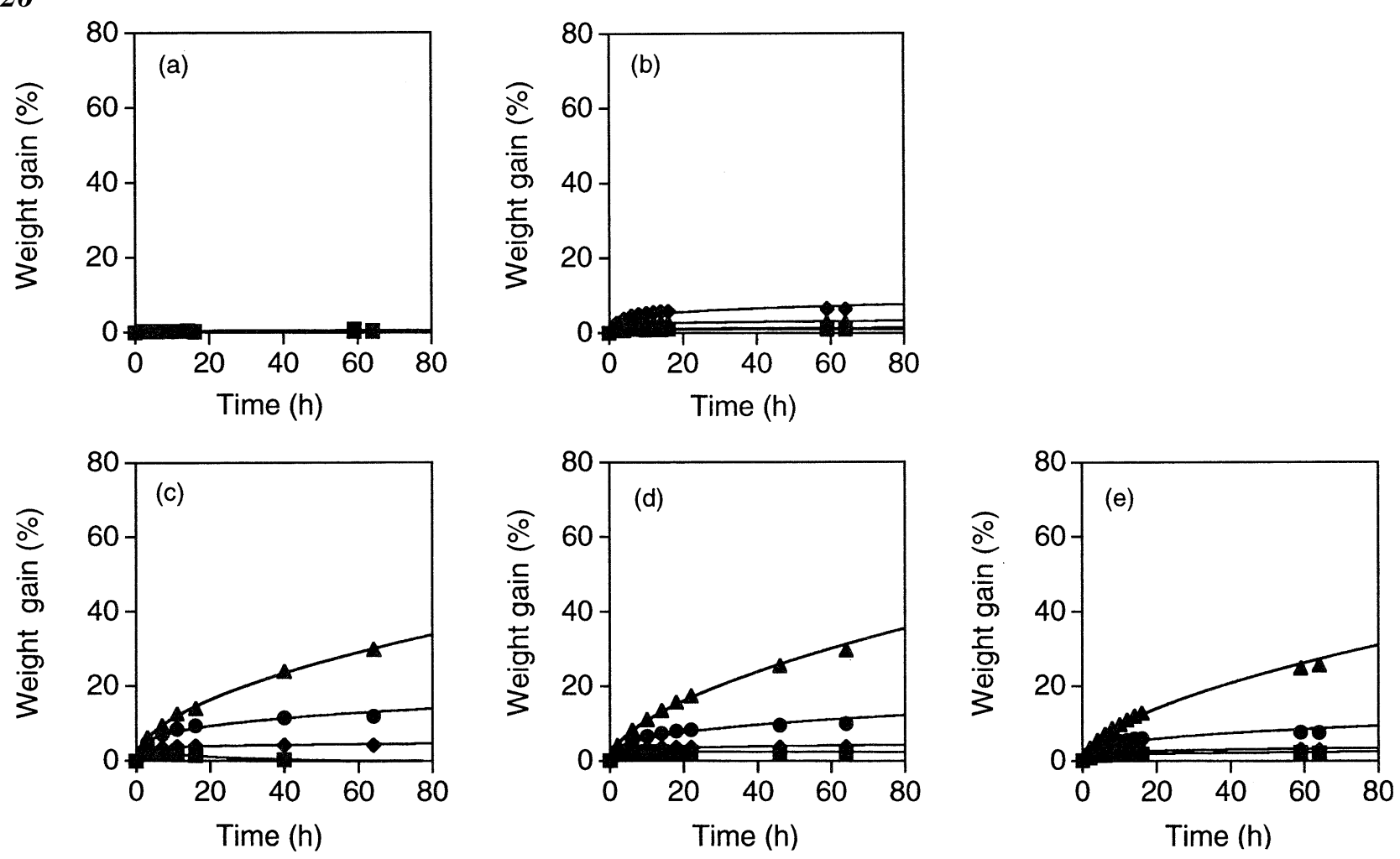

Fig. 4. Changes of Weight Gain of Various Diluents under Various Humidity Conditions at $25^{\circ} \mathrm{C}$.

(a) Lactose ; (b) Crystalline Cellulose ; (c) Neusilin ${ }^{\circledR} \mathrm{NFL}_{2} \mathrm{~N}$; (d) Neusilin ${ }^{\circledR} \mathrm{US}_{2}$;

(e) Neusilin ${ }^{\circledR} \mathrm{UFL}_{2} ; \mathbf{\square}, 51 \% \mathrm{RH} ; \boldsymbol{\bullet}, 62 \% \mathrm{RH} ; \boldsymbol{\Delta}, 75 \% \mathrm{RH} ; \bullet, 90 \% \mathrm{RH}$
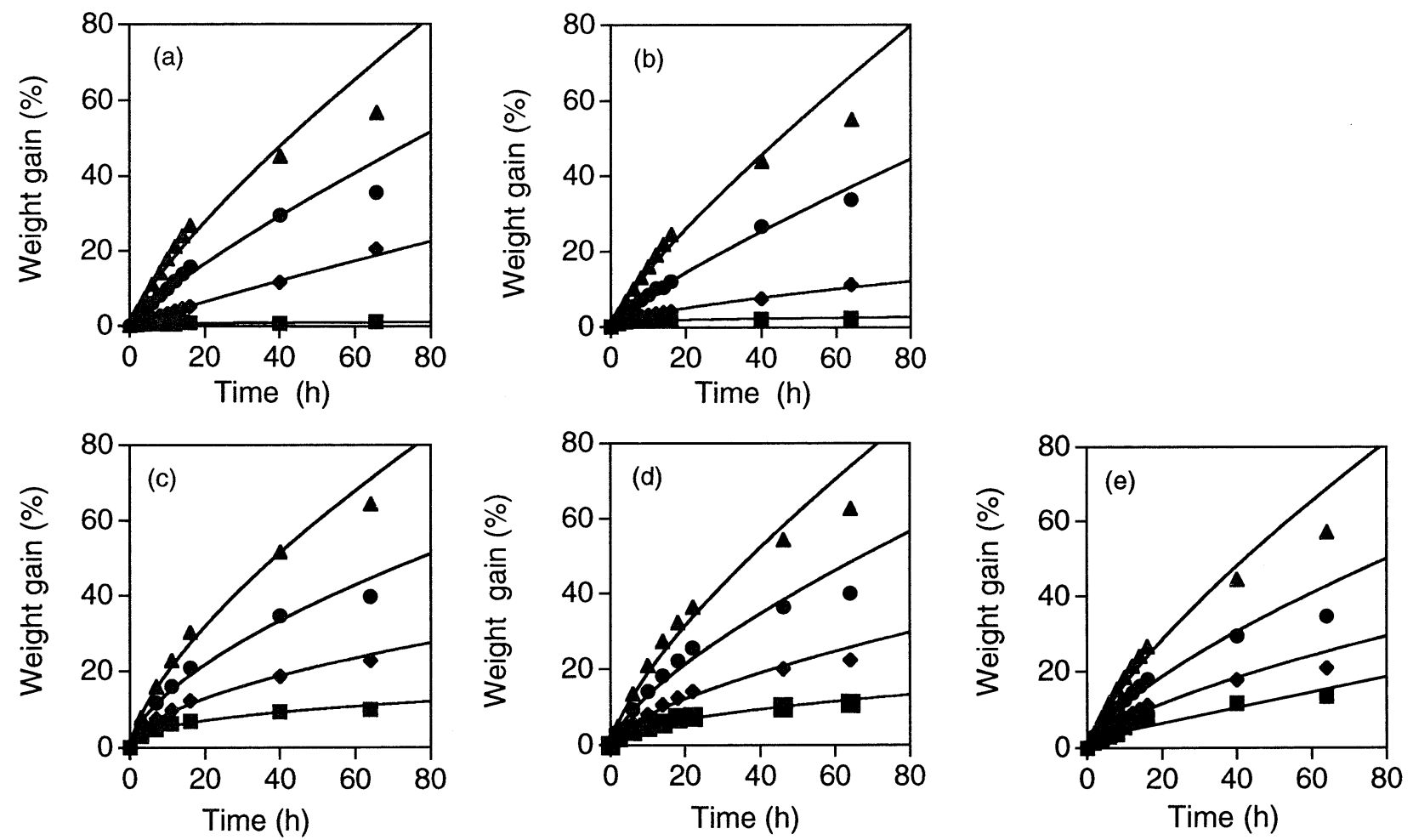

Fig. 5. Changes of Weight Gain of the Mixture of Guanidine Hydrochloride and Diluents under Various Humidity Conditions at $25^{\circ} \mathrm{C}$.

(a) Lactose ; (b) Crystalline Cellulose; (c) Neusilin ${ }^{\circledR} \mathrm{NFL}_{2} \mathrm{~N}$; (d) $\operatorname{Neusilin}^{\circledR} \mathrm{US}_{2}$; (e)

Neusilin ${ }^{\circledR} \mathrm{UFL}_{2} ; \mathbf{D}, 51 \% \mathrm{RH} ; \boldsymbol{\circ}, 62 \% \mathrm{RH} ; \boldsymbol{\Delta}, 75 \% \mathrm{RH} ; \diamond, 90 \% \mathrm{RH}$ 
Table 3. Changes in Angle of Repose of Mixtures of Guanidine Hydrochloride and Various Types of Neusulin ${ }^{\circledR}$ Stored at $25^{\circ} \mathrm{C}$ and $75 \%$ RH for $5 \mathrm{~h}$.

\begin{tabular}{lccc}
\hline \multirow{2}{*}{ Excipient } & \multicolumn{2}{c}{ Angle of repose $^{* 1}\left({ }^{\circ}\right)$} & \multirow{2}{*}{ Ratio (B/A) } \\
\cline { 2 - 3 } & \multicolumn{1}{c}{ Before storage (A) } & After storage (B) & \\
\hline No addition & 43.5 & 56.6 & 1.30 \\
Neusilin $\mathrm{NFL}_{2} \mathrm{~N}$ & 48.1 & 50.0 & 1.04 \\
Neusilin $\mathrm{UFL}_{2}$ & 43.5 & 46.3 & 1.06 \\
Neusilin $\mathrm{US}_{2}$ & 33.2 & 33.6 & 1.01 \\
\hline
\end{tabular}

*1 Samples were stored at $25^{\circ} \mathrm{C}$ and $75 \% \mathrm{RH}$ for $5 \mathrm{~h}$.
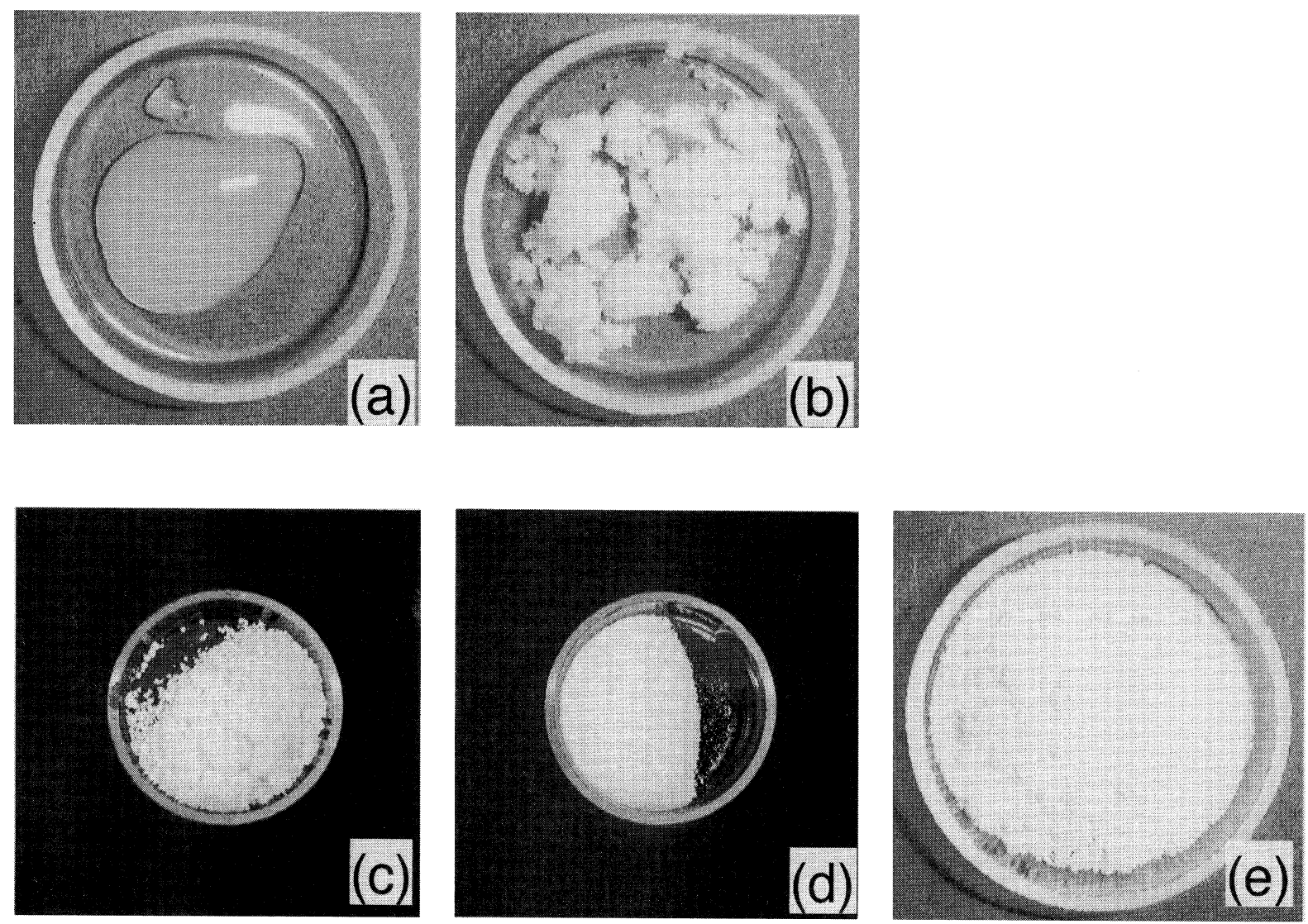

Fig. 6. Appearance Changes of the Mixture of Guanidine Hydrochloride and Diluents after Storage at $75 \% \mathrm{RH}$ for $64 \mathrm{~h}$.

(a) Lactose ; (b) Crystalline Cellulose ; (c) Neusilin ${ }^{\circledR} \mathrm{NFL}_{2} \mathrm{~N}$; (d) Neusilin ${ }^{\circledR}$ $\mathrm{US}_{2} ;$ (e) Neusilin ${ }^{\circledR} \mathrm{UFL}_{2}$

変化しないことから，分包操作にも支障をきたさず，含 量が均一な製剂を調製できると考えられる。

\section{3. 塩酸グアニジンと添加剤の等量混合物の吸湿特性に 及ぼす包装材料の影響}

病院薬剂部では処方薬剤数が多い患者の服薬漏れを防
ぐために，散剤や錠剤などの 1 回量包装調剂が自動分包 機を用いて行われている。この分包機で使用されている 包装材料（グラシン紙，中圧法ポリエチレン樹脂）に塩 酸グアニジンと添加剤の等量混合物を分包し, $25^{\circ} \mathrm{C}, 75 \%$ RH で保存した時の重量増加率を Fig. 7 に示 した. 高山ら は) は種々の包装材料の透湿度について検討 
Table 4. Changes in Liquidity of Various Mixtures of Guanidine Hydrochloride and Diluent Stored at $25^{\circ} \mathrm{C}$ and Various Relative Humidities.

\begin{tabular}{lcccc}
\hline \multirow{2}{*}{ Excipient } & \multicolumn{5}{c}{ Relative humidity $(\%)$} \\
\cline { 2 - 5 } & 51 & 62 & 75 & 90 \\
\hline No addition & + & ++ & +++ & +++ \\
Lactose & + & +++ & +++ & +++ \\
Crystalline cellulose & - & ++ & ++ & ++ \\
Neusilin $\mathrm{NFL}_{2} \mathrm{~N}$ & \pm & \pm & \pm & \pm \\
Neusilin $\mathrm{UFL}_{2}$ & \pm & \pm & \pm & \pm \\
Neusilin $\mathrm{US}_{2}$ & - & - & - & - \\
\hline
\end{tabular}

Symbols used are as follows:

-: no appearance change was observed; \pm : a little solidification ; +: solidification or a slight wetting were observed; ++: appreciable wetting was observed; +++: liquefaction was observed and the sample lost characteristics of powder
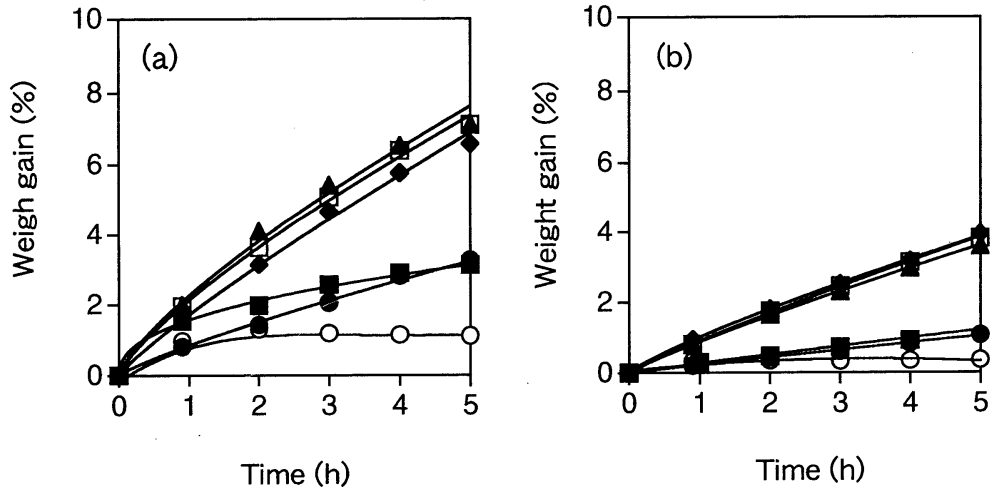

Fig. 7. Effect of Packing Materials on the Hygroscopicity of Guanidine Hydrochloride-Diluents Mixtures.
(a) Glassine paper; (b)
Polyethylene Sheet: $\bigcirc$, Guanidine Hydrochloride alone $\mathbf{\square}$, Lactose; $\mathbf{O}$, Crystalline Cellu- Neusilin ${ }^{\circledR}$ UFL2

しているが，彼らの結果によればグラシン紙よりポリセ 口の方が透湿度が低い。この実験で使用した包装材に混 合粉末を入れずに空のまま同じ条件下で 5 日間保存した

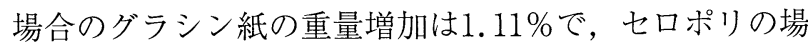
合は $0.35 \%$ となり, わずかにグラシン紙の方が重量増加 率が高くなったが，いずれの場合も包装紙のみでは吸湿 はきわめて少ないと考えられる. しかし, 添加剤と混合 した塩酸グアニジンは Fig. 7 からも明らかなように， 包装材料によって吸湿量に顕著な差異が認められ，いず れの混合物においてもグラシン紙の場合に重量増加が大 きくなった。すなわち，ノイシリンとの等量混合物の場
合, グラシン紙中で保存した場合，5日後には重量が約 7 \%増加したが，セロポリでは約 $4 \%$ で，これは，高山 らが報告しているようにセロポリの透湿度が低いことに 起因していると考えられる.これらに対してセルロース との混合物では 5 日間保存後にグラシン紙中で一部液化 が観察されたが，セロポリでは試料が少し湿った程度に 留まっていた。乳糖との混合物ではいずれの包装材中で も一部固化し，凝集体が認められた。また，ノイシリン $\mathrm{NFL}_{2} \mathrm{~N}$ と UFL 2 との混合物の場合, 包装紙との付着性が 強いため, 服用するのが難しく, 服用量のばらつきが生 じることが予想された。 これらに対してノイシリン $\mathrm{US}_{2}$ 
を添加した塩酸グアニジンは, 保存後もさらさらした状 態で流動性も良く，服用しやすいことが示唆された。

本研究では特殊な処方に基づいて吸湿性医薬品を調製 する場合に，添加する賦形剂を選択することにより，散 剂の流動性を維持することができることを明らかにし た。また塩基性薬物の溶解性を改善するために一般に塩 とされるが，用いる鉱酸の種類によって吸湿性が著しく 変化するため, 塩の選択は物理化学的安定性の面からも 検討する必要性が示唆された。

謝辞 本研究にご協力いただいた鈴木悠子氏に感謝いたし ます。

\section{引用文献}

1) S.J. Oh, D.S. Kim, T.C. Head, G.C. Claussen, Lowdose Guanidine and Pyridostigmine : Relatively Safe and Effective Long-term Symptomatic Therapy in Lambert-Eaton Myasthenic Syndrome, MUSCLE AND NERVE, 20 ( 9), 1146-1152(1997).

2) P. Rondepierre, A. Furby, O. Godefroy, J. F. Hurte- vent, A. Destee, F. Fourrier, D. Leys, Mixed Preand Postsynaptic Neuromuscular Block, REVUE NEUROLOGIQUE, 148 ( 3 ), 193-199 (1992).

3) B. Donald, M.D. Sanders, Lambert-Eaton Myasthenic Syndrome : Clinical Diagnosis, Immune-mediated Mechanisms, and Update on Therapies, Ann. Neurol., 37, 563-572(1995).

4）山下文子，安生紗枝子，近藤由利子，処方から得 た治療情報一Eaton-Lambert 症候群における塩酸 グアニジンの処方例－,薬局, 41, 555-557(1990).

5）日本薬剂師会編, “第11改訂 調剂指針”, 薬事日報 社, 東京, 2001, pp. 105-118.

6) J.M. Michael and I.M. Stein, The colorimetric Determination of Mono and Disubstituted Guanidines, Anal. Biochem., 54, 545-553(1973).

7) P. L. Gould, Salt Selection for Basic Drugs, Int. J. Pharm., 33 (1-3) , 201-217(1986).

8）丹野慶紀，池田實，佐々木吉幸，流動性造粒乳糖 の混合性の評価, 病院薬学, 5(2), 73-79(1979).

9）高山明, 越川富雄, 斉藤一文字, 奥村勝彦, 堀了 平, 上能伊公雄, 北澤式文, 散剂の吸湿とその防 止に関する研究一保存条件, 包装材料の影響一, 病院薬学, 11(5), 414-418(1985). 